\title{
A QUESTIONNAIRE-BASED STUDY ON MEDICINAL PLANT USE IN RESPIRATORY DISEASES
}

\author{
SOLUNUM YOLU HASTALIKLARINDA TIBBİ BITTKİ KULLANIMI ÜZERINE ANKET \\ TABANLI BIR ÇALIŞMA
}

\section{Zeynep Büşra ERARSLAN ${ }^{1}$, Sinan AY ${ }^{1}$, Şükran KÜLTÜR ${ }^{1, *}$}

${ }^{1}$ Department of Pharmaceutical Botany, Faculty of Pharmacy, Istanbul University, 34116, Istanbul, Turkey

\begin{abstract}
Objective: We aimed to investigate the rates of medicinal plant use, species of medicinal plants, detailed usage and procurement information, the sociodemographic features affecting the tendency to use plants and the notification status to healthcare professionals in patients with respiratory diseases.

Material and Method: This study was carried out between January-April 2018 at the Molla Gurani Family Healthcare Center. An 18-item survey questionnaire was administered to patients suffered from respiratory diseases. Analysis were made in SPSS version 26.0 software using both chi-square analysis and Fisher's Exact test.

Result and Discussion: Of the 62 patients, $64.5 \%$ had used medicinal plants to treat respiratory diseases. A total of 14 different plants and plant mixture were determined, most commonly used were mintlemon, licorice, linden and rosehip. Gender $(p=0.01)$ and inhabitation $(p=0.007)$ were significant between the groups that used and did not use plants. The rates of patients' benefiting from plants and recommending plants were also found to be high $(87.5 \%, 90 \%$, respectively). Only $40 \%$ of users had notified their doctor, age $(p=0.029)$, educational status $(p=0.002)$ and inhabitation $(p=0.015)$ were statistically significant for notification to healthcare professionals about plant usage. This study has demonstrated the need for further research into commonly used medicinal plants in respiratory diseases.

Keywords: Complementary alternative medicine, medicinal plants, respiratory diseases

ÖZ

Amaç: Bu çalışmada, solunum yolu hastalıklarında tıbbi bitki kullanım oranının, bitki türlerinin, ayrıntılı kullanım ve satın alma bilgilerinin, bitki kullanma ĕgilimini etkileyen sosyodemografik özelliklerin ve sağlık profesyonellerine bildirim durumlarının araştırılması amaçlanmıştır.
\end{abstract}

\footnotetext{
* Corresponding Author/Sorumlu Yazar: Şükran Kültür e-mail/e-posta: s_kultur@istanbul.edu.tr
} 
Gereç ve Yöntem: Araştırma 2018 yılı Ocak-Nisan ayları arasında Molla Gürani Aile Sağlı̆̆ı Merkezi'nde gerçekleştirildi. Solunum yolu hastalarına 18 maddelik bir anket formu uyguland. Elde edilen verilerin analizleri SPSS sürüm 26.0 yazılımında Ki-kare ve Fisher's Exact testi kullanılarak yapıldl.

Sonuç ve Tartışma: Ankete katılan 62 solunum yolu hastasının 64.5\%'inin tıbbi bitkileri kullandı $\breve{g}$ belirlenmiştir. Toplamda 14 farklı bitki ve bitki karışımının kullanıldığ limon, meyan kökü, ıhlamur ve kuşburnu tercih edildiği görülmüsstür. Bitki kullanan ve kullanmayan gruplar arasında cinsiyet $(p=0.01)$ ve yerleşim $(p=0.007)$ istatistiksel olarak anlamlıdır. Hastaların bitkilerden yararlanma ve bitki tavsiye etme oranlarının da yüksek olduğu görülmüstür (sırasıyla 87.5\%, 90\%). Kullaniclların sadece \%40'ı doktorlarına bitki kullanımını bildirirken, yaş $(p=0,029)$, eğitim durumu $(p=0,002)$ ve yerleşim yerinin $(p=0,015)$ istatistiksel olarak anlamlı olduğ bulunmuştur. Çalışma, solunum yolu hastalıklarında yaygın olarak kullanılan tıbbi bitkiler üzerinde daha fazla araştırma yapılması gerektiğini göstermiş̧tir.

Anahtar Kelimeler: Geleneksel ve tamamlayıcı tıp, solunum yolu hastallklarl, tıbbi bitkiler

\section{INTRODUCTION}

Several types of respiratory diseases such as asthma, bronchitis, chronic obstructive pulmonary disease (COPD) affect millions of people worldwide and cause an immense health burden in many countries. According to the latest estimates, 334 million people suffer from asthma and about 65 million people have COPD. COPD is assumed as the third leading cause of death worldwide, 3 million of the patients die each year [1,2]. In Europe, respiratory diseases rank as the second most common disease in terms of incidence, prevalence, mortality and economic costs [3]. Among respiratory diseases, COPD and lower respiratory system infections are regarded as leading conditions which can cause a death for all age groups and for both sexes in Turkey [4]. Though there are many risk factors have been identified, Tobacco smoking is the main one which is directly responsible for the morbidity and mortality resulting from respiratory diseases [3,4]. As stated by Turkey Statistical Institute (TUIK) database, respiratory system diseases is the third (10.15\%) main cause of death between 2009-2016 in Turkey. The distribution of disorders among respiratory diseases is as follows: COPD, 59.44\%; pneumonia, $21.50 \%$; asthma, $4.91 \%$; acute upper respiratory diseases and flu, $0.64 \%$; others, $13.52 \%$, respectively. Death rates from respiratory diseases are higher among male (60\%) than among female (40\%). It was also found that mortality from COPD and bronchiectasis was 2 times higher in males than in females. Regarding the malignancies, respiratory malignancies were the most common tumors with a rate of 30.6\% [5].

Recent years research in respiratory medicine and related technology is in an advanced stage. With modern treatments, symptoms can be controlled and morbidity rate decreases day by day [2,3]. However, maintaining respiratory health is a major issue before illness occurs. Besides various available effective methods in modern/conventional therapy, complementary alternative medicine 
(CAM) is also preferred by most people looking for cheaper and traditional different methods to prevent and treat respiratory diseases [6,7].

Current definition of CAM is "any diagnosis, treatment and/or prevention which complements mainstream medicine by contributing to a common whole, by satisfying a demand not met by orthodoxy or by diversifying the conceptual frameworks of medicine". During the last decades, the popularity of CAM has increased steadily, and these practices have become applicable by healthcare professionals under government supervision in developing countries [8-10]. It is known that in Europe, North America and other industrialized regions, approximately $70 \%$ of the population use at least one of the CAM practices. Although CAM has over 150 known treatment modalities (homeopathy, hypnotherapy, energy therapies, Ayurveda, e.g.), herbal medicine is the most common therapy in Turkey $[8,11,12]$.

As a result of floristic richness, Turkey is one of the leading countries in terms of traditional herbal medicine usage. It has more than 11000 plant species with a nearly $34 \%$ endemism rate, which is almost equivalent to the entire European continent. Different civilizations settled in Anatolia lands bringing different cultures and customs have constituted an extensive accumulation of knowledge on traditional herbal medicine. Therefore, most people today benefit from medicinal plants for primary healthcare in the light of past knowledge and previous experience $[13,14]$.

The use of medicinal plants has also been widely embraced in many developed countries. About 120000 plant species are used for nutrition or medical purposes all over the world and approximately $25 \%$ of today's modern drugs in the world is originated from medicinal plants $[15,16]$. In recent years, there has been a significant increase in medicinal plant research which evaluate effectiveness and safety of medicinal plants. These studies play an important role in the field of new drugs research and development. On the other hand, the number of companies producing herbal medicine based on quality and standards of synthetic pharmaceutical production has increased $[6,11,16,17]$. Recent studies revealed that herbal medicines are generally used by patients with common chronic diseases including breast cancer (12\%), liver diseases (21\%), HIV (22\%), asthma (24\%) and rheumatologic disorders (26\%) [17]. However, information on medicinal plant usage for the treatment of respiratory diseases is limited in Turkey $[10,18]$. To address this need, we aimed to determine the frequency of medicinal plant use, species of medicinal plants, detailed usage and procurement information, the sociodemographic features affecting the tendency to use plants and the notification status to healthcare professionals in patients with respiratory diseases. 


\section{MATERIAL AND METHOD}

\section{Participants and questionnaires}

A questionnaire-based survey design was used to collect data on use of medicinal plants in respiratory diseases. The study was conducted between January-April 2018 at the Molla Gurani Family Healthcare Centre. Approval was sought from the authorities by the official correspondence between the board of Faculty of Pharmacy and Family Healthcare Center. The questionnaire was filled out by 62 participants ( 18 years of age or older) diagnosed with respiratory disease. Before performing face-to-face interviews, information was given about the aim of the study and verbal consent was obtained. The questionnaire was designed specifically for this study and consisted of 18 questions. Most of them were multiple-choice questions; however, the participants were able to add other answers. The questionnaire consists of the following main themes: sociodemographic data (age, gender, place of residence, education), medical data (type of respiratory disease), detailed data on usage of medicinal plants (whether they use plants, plant species, reason for using plants, used parts and preparation, advice-benefits, procurement) and the notification status to healthcare professionals (drug or plant usage, response of healthcare professionals).

\section{Statistical analysis}

The obtained data were recorded and analyzed using Microsoft Office Excel and Statistical Package for the Social Sciences (SPSS) version 26.0 software. Both chi-square analysis and Fisher's Exact Test was used to determine the statistical significance of differences between groups. A p value less than 0.05 were taken to indicate statistical significance.

\section{RESULT AND DISCUSSION}

There were 62 patients included in the study, 36 of which were female and 26 were male. $70 \%$ of those who indicated that they had used plants in respiratory diseases was female. Patients came from a wide age range and the majority of patients were between 18-24 years of age (40.3\%). Education was on a scale ranging from illiteracy to university graduates. The participants resided either in the urban or in the rural. The detailed sociodemographic features profile of participants who use plants or not are given in Table 1 . Gender $(\mathrm{p}=0.01)$ and inhabitation $(\mathrm{p}=0.007)$ were statistically significant for plant usage in respiratory diseases. Females and patients who live in urban were more likely to use plants. But no significant difference was determined between plant users and non-users in terms of age and education status ( $p>0.05)$. 
Table 1. Sociodemographic profiles of participants.

\begin{tabular}{|c|c|c|c|c|}
\hline \multirow{2}{*}{ Characteristics } & & \multicolumn{3}{|c|}{ Plant use } \\
\hline & & Yes, n (\%) & No, n (\%) & Total, n (\%) \\
\hline \multirow[t]{4}{*}{ Age $p>0.05$} & $18-24$ & $11(27.5 \%)$ & $14(63.6 \%)$ & $25(40.3 \%)$ \\
\hline & $31-40$ & $5(12.5 \%)$ & $1(4.5 \%)$ & $6(9.7 \%)$ \\
\hline & $41-50$ & $3(7.5 \%)$ & $2(9.1 \%)$ & $5(8.1 \%)$ \\
\hline & $51-60$ & $6(15 \%)$ & $0(0 \%)$ & $6(9.7 \%)$ \\
\hline \multirow[t]{2}{*}{ Gender $\mathrm{p}=\mathbf{0 . 0 1}$} & Female & $28(70 \%)$ & $8(36.4 \%)$ & $36(58.1 \%)$ \\
\hline & Male & $12(30 \%)$ & $14(63.6 \%)$ & $26(41.9 \%)$ \\
\hline \multirow[t]{3}{*}{ Education status p>0.05 } & Illiterate & $2(5 \%)$ & $0(0 \%)$ & $2(3.2 \%)$ \\
\hline & Primary school & $5(12.5 \%)$ & $1(4.5 \%)$ & $6(9.7 \%)$ \\
\hline & Middle school & $5(12.5 \%)$ & $1(4.5 \%)$ & $6(9.7 \%)$ \\
\hline Inhabitation $\mathrm{p}=\mathbf{0 . 0 0 7}$ & Rural & $14(35 \%)$ & $1(4.5 \%)$ & $15(24.2 \%)$ \\
\hline
\end{tabular}

$54.8 \%$ of the participants used vitamin-mineral at various frequency, whereas $45.2 \%$ of the participants did not use. They consumed vitamins-minerals every day, 3-4 times a week or 3-4 times a month. Majority of consumers used only when they feel bad (27.4\%). The relation between vitaminmineral usage and sociodemographic features was examined and no statistical differences were found $(\mathrm{p}>0.05)$. A total of 8 main respiratory diseases were determined in patients and their prevalance are listed as follows: flu-cold (38.7\%), upper respiratory tract infection (14.5\%), asthma (12.9\%), cough (11.3\%), COPD (9.7\%), pharyngitis (6.5\%), rhinitis (3.2\%), tonsillitis (3.2\%). Flu-cold was the most common disease that affect female and male patients. In the second place, while females suffered from asthma (19.4\%), males suffered from both COPD (15.4\%) and upper respiratory tract infection $(15.4 \%)$. Detailed data is presented in Table 2.

Table 2. The medical data of participants.

\begin{tabular}{|c|c|c|c|c|}
\hline Characteristics & & Female, n (\%) & Male, n (\%) & Total, n (\%) \\
\hline \multirow{4}{*}{$\begin{array}{l}\text { Frequency of vitamin- } \\
\text { mineral usage }\end{array}$} & Everyday & $4(11.1 \%)$ & $1(3.8 \%)$ & $5(8.1 \%)$ \\
\hline & 3-4 times a month & $4(11.1 \%)$ & $1(3.8 \%)$ & $5(8.1 \%)$ \\
\hline & Only when I feel bad & $9(25.0 \%)$ & $8(30.8 \%)$ & $17(27.4 \%)$ \\
\hline & No & $15(41.7 \%)$ & $13(50 \%)$ & $28(45.2 \%)$ \\
\hline \multirow{6}{*}{ Respiratory disease } & Rhinitis & $2(5.6 \%)$ & $0(0 \%)$ & $2(3.2 \%)$ \\
\hline & Tonsillitis & $1(2.8 \%)$ & $1(3.8 \%)$ & $2(3.2 \%)$ \\
\hline & Asthma & $7(19.4 \%)$ & $1(3.8 \%)$ & $8(12.9 \%)$ \\
\hline & Pharyngitis & $1(2.8 \%)$ & $3(11.5 \%)$ & $4(6.5 \%)$ \\
\hline & Cough & $4(11.1 \%)$ & $3(11.5 \%)$ & $7(11.3 \%)$ \\
\hline & $\begin{array}{l}\text { Chronic obstructive pulmonary } \\
\text { disease }\end{array}$ & $2(5.6 \%)$ & $4(15.4 \%)$ & $6(9.7 \%)$ \\
\hline
\end{tabular}


A total of 40 participants used plants for the treatment of respiratory diseases, as can be seen in Figure 1. A wide range of herbs were used for respiratory diseases; patients reported that they had used 14 different types of plants and plant-mixture to treat different conditions. The most popularly used plants and plant-mixture were mint-lemon, licorice, linden and rosehip, their common names are given (Figure 2). It was found that the leaves were the most frequently used part of the plant, accounting for $30 \%$. Following in this category are fruits (23\%), seeds (17\%), stem (10\%), aerial parts $(7.5 \%)$, flowers (7.5\%) and roots (5\%) (Figure 3). Infusion (55\%) was the most commonly used preparation method, others are given in Figure 4.

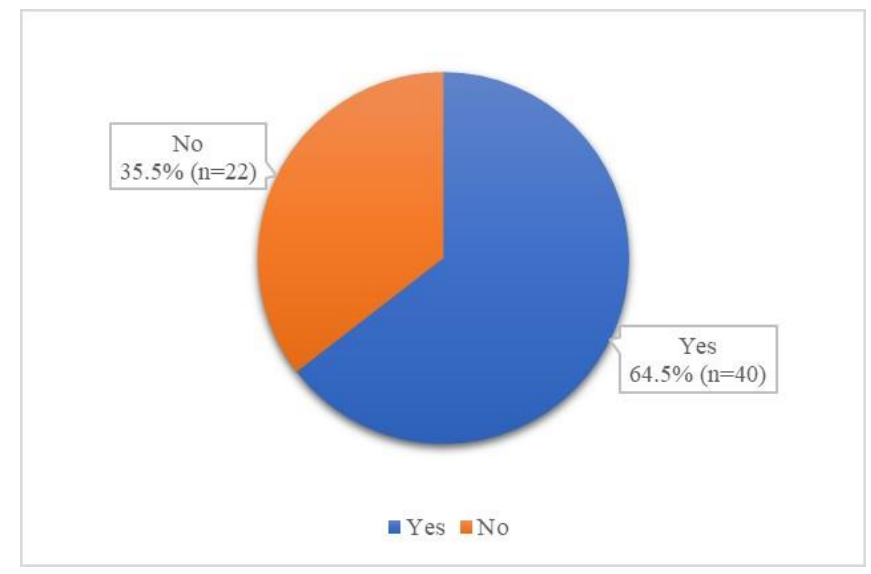

Figure 1. A rate of total plant usage for the treatment of respiratory diseases.

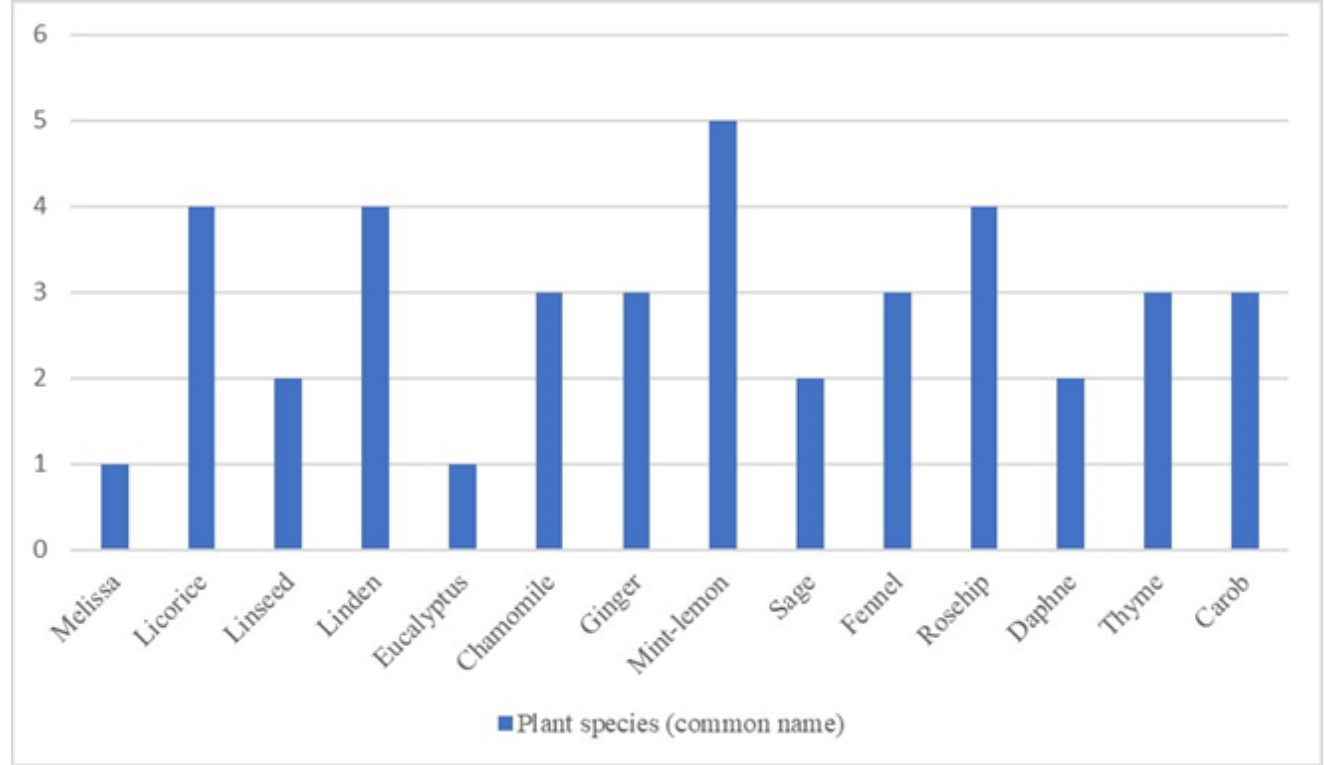

Figure 2. Plants and plant-mixture used for the treatment of respiratory diseases. 


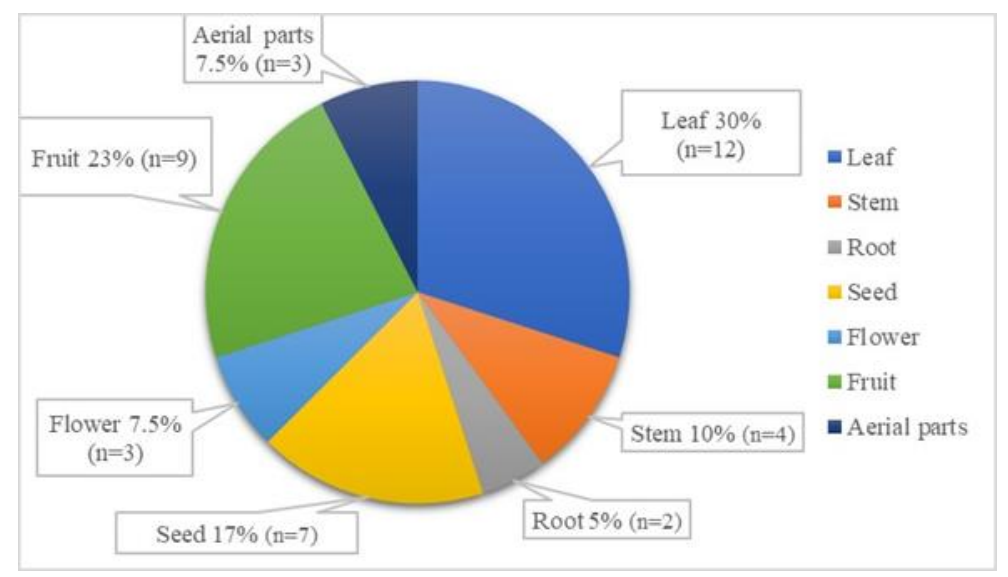

Figure 3. Plant parts used for the treatment of respiratory diseases.

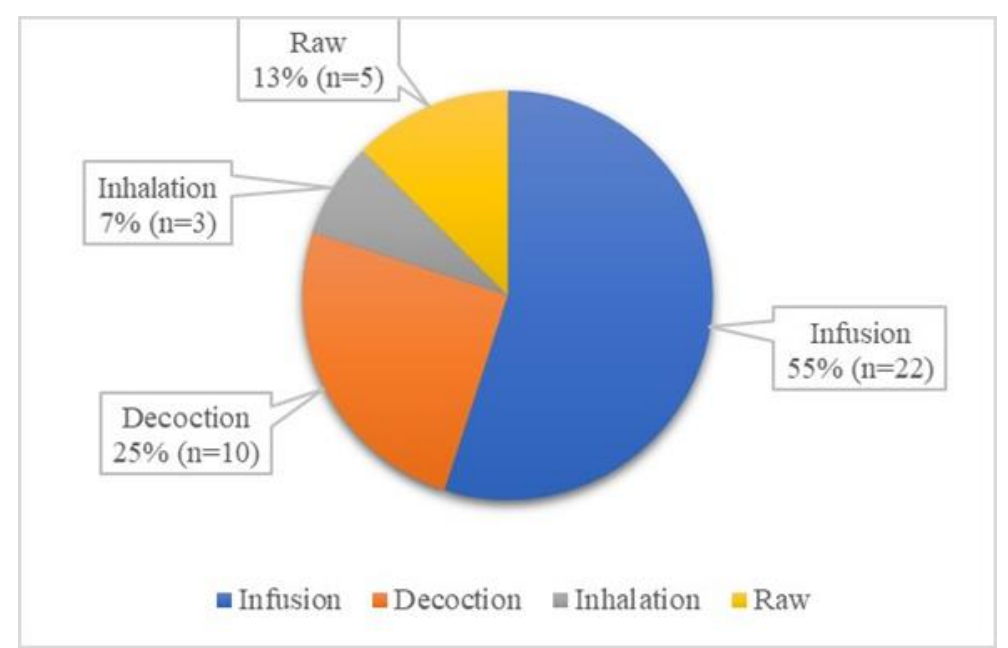

Figure 4. Preparation methods of plants used for the treatment of respiratory diseases.

Patients preferred plants for various reasons, primarily to help treatment (40\%). They also used plants to feel good (30\%), to treat disease (25\%), and small number of patients used to reduce side effects (5\%). Participants often purchased plants at a cost of between 0-50 tl (80\%). Only $2 \%$ stated they bought plants at a cost of $500 \mathrm{TL}$ and over. Participants said that they provided their medicinal plants usually from friends and relatives (37.5\%), followed by herbalist (22.5\%), other (17.5\%) and pharmacist (15\%). TV (5\%) and Internet (2.5\%) were very rarely cited sources. When asked about the effectiveness, most of the participants indicated that medicinal plants were beneficial (87.5\%). A large majority of patients recommended the plants to other people (90\%). There was no significant difference between sociodemographic features and data on plant usage (reasons, money, sale channel, benefit status, recommendation) ( $p>0.05$ ), except for inhabitation-sale channel preferences 
$(\mathrm{p}=0.014) .30 .8 \%(\mathrm{n}=8)$ of participants who live in city center consulted herbalist to buy plants, whilst who live in village supplied their plants from friends and relatives $(64.3 \%, \mathrm{n}=9)$ (Table 3).

Table 3. Detailed data on plant usage of patients.

\begin{tabular}{|c|c|c|}
\hline Characteristics & & n(\%) \\
\hline \multirow{4}{*}{ Reasons for plant use } & To treat disease & $10(25 \%)$ \\
\hline & To help treatment & $16(40 \%)$ \\
\hline & To feel good & $12(30 \%)$ \\
\hline & To reduce side effects & $2(5 \%)$ \\
\hline \multirow[t]{4}{*}{ Money paid by patients to supply plants } & $0-50$ tl & $32(80 \%)$ \\
\hline & $50-100 \mathrm{tl}$ & $4(10 \%)$ \\
\hline & $100-500 \mathrm{tl}$ & $2(5 \%)$ \\
\hline & $500 \mathrm{tl}$ and over & $2(5 \%)$ \\
\hline \multirow[t]{6}{*}{ Sale channel preferences } & Herbalist & $9(22.5 \%)$ \\
\hline & Pharmacist & $6(15 \%)$ \\
\hline & Internet & $1(2.5 \%)$ \\
\hline & Friends and relatives & $15(37.5 \%)$ \\
\hline & TV & $2(5 \%)$ \\
\hline & Other & $7(17.5 \%)$ \\
\hline \multirow[t]{3}{*}{ Benefit status of plants } & Beneficial & $35(87.5 \%)$ \\
\hline & Harmful & $2(5 \%)$ \\
\hline & Neutral & $3(7.5 \%)$ \\
\hline \multirow{2}{*}{ Recommendation of plant use } & Yes & $36(90 \%)$ \\
\hline & No & $4(10 \%)$ \\
\hline
\end{tabular}

About a third of people said that they got approval from their doctor before taking a drug (33.9\%). Additionally, only $40 \%$ of participants informed healthcare professionals about plants they had used. More than half of the informers stated that healthcare professionals approved the plant usage. According to the patients, other responses which they got from healthcare professionals were left my choice $(18.8 \%)$, against the plant usage (12.5\%) and no comment (12.5\%). Analysis demonstrated that age $(\mathrm{p}=0.029)$, educational status $(\mathrm{p}=0.002)$ and inhabitation $(\mathrm{p}=0.015)$ were statistically significant for notification to healthcare professionals about plant usage. Participants who $18-24$ years of age $(50 \%, \mathrm{n}=8)$, graduated from a university $(81.3 \%, \mathrm{n}=13)$ and live in city center $(87.5 \%, n=14)$ were more likely to inform healthcare professionals about plant usage (Table 4).

Table 4. Notification to healthcare professionals.

\begin{tabular}{llc}
\hline Characteristics & & $\mathbf{n}(\%)$ \\
\hline Taking drug without consulting doctors & Yes & $41(66.1 \%)$ \\
& & $21(33.9 \%)$ \\
Notification to healthcare professionals about plant usage & No & $16(40 \%)$ \\
& No & $24(60 \%)$ \\
Response of healthcare professionals & Against the plant use & $2(12.5 \%)$ \\
& Approved & $9(56.3 \%)$ \\
& Left my choice & $3(18.8 \%)$ \\
& No comment & $2(12.5 \%)$ \\
\hline
\end{tabular}


Turkey is one of the leading country in terms of using herbs as medicines, drawn from a rich inventory of indigenous natural ingredients. The cultural beliefs and attitudes to herbal medicines have a long history and people still prefer herbs for primary healthcare, particularly in rural areas. Although many local studies have been carried out to investigate the prevalence of medicinal plant use in Turkey, few have focused specifically on patients with respiratory diseases $[10,18]$.

This questionnaire-based survey provides detailed information about the use of medicinal plants in respiratory diseases. More than half $(64.5 \%)$ of the respiratory disease patients reported using some species of plants, with some differences regarding sociodemographic factors. The results indicate that women use plants at greater rates than men do. We also found that people who live in urban areas are more likely to use plants. Many studies conducted worldwide have suggested that women are leading the way in using alternative therapies [19-22].

The most commonly used medicinal plants found in this study were different to previously published studies [20,23-26]. Impact of geographical and cultural variations may also bring out this result. It has been found that there are pharmacological studies supporting the use of these plants in respiratory diseases. While some medicinal plants have more than one medically used species, we researched by the most commonly known scientific names. As a result of our study, the mixture of mint-lemon was determined as most frequently used plant mixture to treat respiratory diseases and related conditions. Lemon (Citrus limon L.) has very rich bioactive compounds including citric acid, ascorbic acid, minerals, flavonoids and essential oils. Thanks to the anti-inflammatory, antioxidant and antiallergic effects of the main flavonoids (quercetin, hesperidin, rutin), lemon is thought as beneficial in respiratory diseases such as bronchitis and asthma [27]. C. limon is also a rich source of vitamin $\mathrm{C}$, which has an important antioxidant activity [28]. The results from previous study indicated that phenolic and flavonoid compounds of $C$. limon extracts are correlated with a significant antioxidant activity [29]. Furthermore, its essential oil is mainly used to strengthen the immune system [30]. Similar to lemon essential oil, peppermint (Mentha piperita L.) oil has various medicinal properties and is used in folk medicine for respiratory diseases as expectorant and anticongestive. Its leaf is also traditionally used to treat common cold, inflammation of the mouth and pharynx. Antispasmodic activity of peppermint essential oil on rat trachea with the involvement of prostaglandins and nitric oxide synthase has been shown by in vivo study [31]. Antioxidant, antimicrobial, antiviral, antiallergic and antiinflammatory activities of $M$. piperita (peppermint) has been proven in diverse studies. In particular, remarkable antimicrobial activity against Escherichia coli, Streptococcus aureus and Pseudomonas aeruginosa is promising for the usage as a remedy in respiratory diseases [32]. Glycyrrhiza glabra L. (licorice) possess important bioactive constituents such as triterpenoid saponin, flavonoids, tannins, alkaloids, phenolic compounds. The licorice 
powder and extract are considered to be useful for the treatment of sore throat, cough and bronchial catarrh. It shows anti-tussive and expectorant activity by accelerating tracheal mucus secretion. Glycyrrhizin, an active compound of G. glabra, is contributed the demulcent effect. Moreover, antibacterial (against E. coli, P. aeruginosa, Salmonella typhimurium, S. aureus), antioxidant, antiviral (Severe Acute Respiratory Syndrome) and immuno-modulator (H1N1 Flue) effects have been demonstrated in several in vitro and in vivo studies [33,34]. Tilia platyphyllos Scop. (linden) is traditionally used in folk medicine. While infusion of flowers is prepared for the treatment of asthma and cough, decoction is used in cold and flu in Turkey [35]. Previous phytochemical and pharmacological investigations revealed antibacterial (against Klebsiella pneumoniae, S. aureus) and antioxidant activity of Tilia sp. owing to its rich chemical composition. The inflorescence of the Tilia sp. comprises polysaccharides (mucilaginous), condensed tannins, flavonoids, quercetin glycosides (rutin, quercitrin, and isoquercitrin), kaempferol glycosides and phenolic acids (caffeic, p-coumaric, and chlorogenic acids) [36]. In traditional medicine, Rosa canina L. (rosehip) fruits are used to treat various respiratory diseases such as common cold, flu, vitamin $\mathrm{C}$ deficiency and lung diseases. Vitamin $\mathrm{C}$, which contributes to its potent antioxidant effect, is highly present in rosehip. Also, tannins and other bioactive compounds might provide its anti-inflammatory potentials [37,38]. Antibacterial activity against Gram positive and Gram negative bacterial species has been observed in various in vitro assays [37,39].

Pharmacological effects that can help treat respiratory diseases have been demonstrated in several studies, however, it is substantial to inform patients about the overdose and side effects of some herbs, as well as possible drug interactions. Licorice root can lead to pseudohyperaldosteronism. Patients were reported with long-standing hypokalemia and uncontrolled hypertension related to excessive ingestion of licorice [40]. Combination of ginger (Zingiber officinale Roscoe) and blood diluent medicines is not recommended due to strong inhibition effect of ginger on thromboxane synthetase. Long-term use of ginger may prolong bleeding time [41]. Moreover, care should be taken when providing plants that can be replaced with other harmful plant species. For instance, instead of Matricaria chamomilla L. (chamomille), similar species such as Senecio sp. and Anthemis cotula L., which contain toxic or allergic substances, can be taken from improper sale channels [42].

In our study, $87.5 \%$ of patients using medicinal plants stated that they benefited from the plants they had used. In addition to the pharmacological effects of these plants, the use of plants may reveal a general well-being of the person as a result of the positive psychological effect in patients. Previous studies reported that people use alternative therapies generally to add benefit to modern therapy or to cure illness $[11,19]$. In our study, most of the patients had used medicinal plants to help treatment. 
There are some studies have emphasized communication gaps between healthcare professionals and patients in herbal therapies $[11,19,22]$. Patient-doctor communication and patient education about herbalism need to be improved. We detected $60 \%$ of the plant users stated that they did not report their plant use to the healthcare professionals. Our research shows that age, place of residence, and educational status have impact on the doctor-patient relationship. The majority of those who reported plant usage to the healthcare professionals stated that the healthcare professionals approved their usage. It seems that there is a prejudice in patients against healthcare professionals, and they do not want to share information about plants. Taking drug without consulting doctors was also found high $(66.1 \%)$. These results can lead to undesirable consequences such as side effects, drug interactions, therefore healthcare professionals must inquire about plant use while taking an anamnesis.

$90 \%$ of the plant users reported that they recommend the plants they use to other patients. Biçen et al. [43] reported that the source of information about the herbal product are the neighbor, relative and friend. However, it was observed that plants are generally provided from friends and relatives, and herbalists are preferred as the second option. Doğu et al. [19] stated that cancer patients usually prefer to shop from stores for herbal products. A survey from Western Australia indicated that the majority of the breastfeeding women had purchased their herbal medicines from community pharmacies [44]. According to our results, the place of residence affects the supply of plants. Unconscious consumption of plants that are sold in herbalists, various markets and TV-Internet, may be concluded with serious conditions. Patients should primarily prefer pharmacies to obtain the medicinal plants. Since the information about the use of plants is largely learned by the relatives and friends, it is critical for the public health to use the proper plants under the control of the doctor and the consultancy of the trained pharmacist [42]. Most patients spend money around 0-50 TL for purchase herbs. Supporting this outcome, it is seen that the most frequently used plants in respiratory diseases are everyday household or easily accessible products, which reduces costs.

There are also several limitations that should be mentioned. The survey population was relatively small, study was carried out in a single institution involving generally defined populations of respiratory diseases patients. Healthcare professionals should have been involved in this study. Although we account for several variables in our statistical analyses, other sociodemographic and related factors that were not taken in questionnaire may better account for medicinal plant use. While further studies may be warranted to investigate the attitudes toward medicinal plants in larger populations and with more variables, this present study offer useful information on the overall medicinal plant use in respiratory diseases.

This survey demonstrates a high prevalence of medicinal plant use among patients suffered from respiratory diseases. In total, 14 different plants-plant mixture were determined, most frequently 
used were lemon-mint, licorice, linden and rosehip. It is known that medicinal plants are candidate for a source of biological and pharmacological products for the future. Although there is a lack of clinical studies in medicinal plants for many respiratory diseases, the general safety and efficacy data that do exist can lead us in its potential use or further investigation. More pharmacological studies, especially clinical studies regarding the efficacy and safety of medicinal plants are needed. While treatment with plants are even more popular, perceived as moderately effective and inexpensive, doctors should be routinely inquiring into its usage to avoid undesirable results. It is believed that by increasing the knowledge on phytotherapy, the patient-doctor relationship can progress more accurately in terms of treatment compliance and plant usage. This area deserve more careful selection and monitoring due to pharmacological activity, improper use and inability to control their side effects.

\section{REFERENCES}

1. Yorgancioğlu, A. (2019). The global burden of chronic airway diseases. In: I. Agache and P. Hellings (Eds.), Implementing Precision Medicine in Best Practices of Chronic Airway Diseases, (pp. 33-37). Cambridge: Academic Press.

2. Jardins, T.D., Burton, G. (2020). Clinical Manifestations and Assessment of Respiratory Disease, 8th ed, Mosby, London.

3. Brennan, N.J. (2017). Respiratory Diseases: Overview. In: S.R. Quah, (Ed.), International Encyclopedia of Public Health, 2nd ed, (pp. 328-331). Massachusetts: Academic Press.

4. Yorgancioğlu, A., Türktaş, H., Kalaycı, O., Yardim, N., Buzgan, T., Kocabaş, A., Karlikaya, C., Yildiz, F., Ergün, P., Mungan, D., Kart, L., Göktaş, E., Musaonbaşioğlu, S., Gündoğan, A., Akdağ, R., Akçay, S., Akin, M., Akkurt, I., Altan, P., Altunsu, T., ... Bousquet, J. (2009). The WHO global alliance against chronic respiratory diseases in Turkey (GARD Turkey). Tüberküloz ve Toraks 2009, 57(4), 439-452.

5. Akturan, S., Gümüş, B., Özer, Ö., Balandız, H., Erenler, A. (2019). TÜIK verilerine göre Türkiye'de 2009 ve 2016 yılları arasındaki ölüm oranları ve nedenleri. Konuralp Medical Journal, 11(1), 9-16.

6. Asadbeigi, M., Mohammadi, T., Rafieian-Kopaei, M., Saki, K., Bahmani, M., Delfan, M. (2014). Traditional effects of medicinal plants in the treatment of respiratory diseases and disorders: An ethnobotanical study in the Urmia. Asian Pacific Journal of Tropical Medicine, 7, 364-368.

7. Ekor, M. (2014). The growing use of herbal medicines: issues relating to adverse reactions and challenges in monitoring safety. Frontiers in Pharmacology, 4, 1-10.

8. Ernst, E., Fugh-Berman, A. (2002). Complementary and alternative medicine: What is it all about? Occupational and Environmental Medicine, 59(2), 140-144. 
9. Algier, L.A., Hanoğlu, Z., Özden, G., Kara, F. (2005). The use of complementary and alternative (non-conventional) medicine in cancer patients in Turkey. European Journal of Oncology Nursing, 9(2), 138-146.

10.Orhan, F., Sekerel, B.E., Kocabaş, C.N., Saçkesen, C., Adalığlu, G., Tuncer, A. (2003). Complementary and alternative medicine in children with asthma. Annals of Allergy, Asthma \& Immunology, 90(6), 611-615.

11.Özçelik, G., Toprak, D. (2015). Bitkisel tedavi neden tercih ediliyor? Ankara Medical Journal, $15(2), 48-58$.

12.Şahin, S. (2017). Geleneksel, tamamlayıcı, alternatif tıp uygulamalarına genel bir bakış. Türkiye Aile Hekimliği Dergisi, 21(4), 159-162.

13.Güner, A., Aslan, S., Ekim, T., Vural, M., Babaç, M.T. (2012). Türkiye Bitkileri Listesi (Damarlı Bitkiler), Nezahat Gökyiğit Botanik Bahçesi ve Flora Araştırmaları Derneği Yayınları, İstanbul.

14.Erarslan, Z.B., Kültür, Ş. (2019). Ethnoveterinary medicine in Turkey: a comprehensive review. Turkish Journal of Veterinary and Animal Sciences, 43, 555-582.

15.Dutta, T., Paul, A., Majumder, M., Sultan, R.A., Emran, T.B. (2020). Pharmacological evidence for the use of Cissus assamica as a medicinal plant in the management of pain and pyrexia. Biochemistry and Biophysics Reports, 21, 1-8.

16.Yeşilada, E. (2013). An overview of Turkish folk medicine; past and present. Current Drug Delivery, 10, 1-4.

17.Şarışen, O., Çalışkan, D. (2005). Fitoterapi: Bitkilerle Tedaviye Dikkat. Journal of Contemporary Medical Education, 8(14), 182-187.

18.Kalyoncu, A.F., Selçuk, Z.T., İskendarani, A., Coplu, L., Emri, S., Şahin, A.A., Barış, Y.I. (1992). Alternative and complementary medicine for asthma. Thorax, 47, 762.

19.Doğu, G., Kargı, A., Tanrıverdi, Ö., Yaren, A., Demiray, G., Taşköylü, B.Y., Ergin, A. (2014). Complementary/Alternative medicine experience in cancer patients: A questionnaire-based survey. International Journal of Hematology and Oncology, 24, 1-10.

20.Blanc, P.D., Trupin, L., Earnest, G., Katz, P.P., Yelin, E.H., Eisner, M.D. (2001). Alternative therapies among adults with a reported diagnosis of asthma or rhinosinusitis. Chest, 120(5), 14611467.

21.Feldman, R.H., Laura, R. (2004). The use of complementary and alternative medicine practices among australian university students. Complementary Health Practice Review, 9(3), 173-179.

22.Chang, K.H., Brodie, R., Choong, M.A., Sweeney, K.J., Kerin, M.J. (2011). Complementary and alternative medicine use in oncology: A questionnaire survey of patients and health care professionals. BMC Cancer, 11(1), 1-9.

23.Chung, Y., Dumont, R.C. (2011). Complementary and alternative therapies: Use in pediatric pulmonary medicine. Pediatric Pulmonology, 46(6), 530-544. 
24.Ziment, I., Tashkin, D.P. (2000). Alternative medicine for allergy and asthma. Journal of Allergy and Clinical Immunology, 106(4), 603-614.

25.Sorkness, R.L. (2009). CAM and Respiratory Disease. Nutrition in Clinical Practice, 24(5), 609615.

26.Akan, H. (2012). Herbal and nonpharmacological therapies in upper respiratory tract infections. The Journal of Turkish Family Physician, 3, 9-15.

27.Dahima, R., Mishra, S., Rathore, D. (2016). In-vitro antioxidant and reducing potential activity of extracts of Citrus limon and Solanum lycopersicum. Der Pharmacia Lettre, 8, 258-269.

28.González-Molina, E., Domínguez-Perles, R., Moreno, D.A., García-Viguera, C. (2010). Natural bioactive compounds of Citrus limon for food and health. Journal of Pharmaceutical and Biomedical Analysis, 51(2), 327-345.

29.Makni, M., Jemai, R., Kriaa, W., Chtourou, Y., Fetoui, H. (2018). Citrus limon from Tunisia: Phytochemical and physicochemical properties and biological activities. BioMed Research International, 2018, 1-10.

30.Ali, B., Al-Wabel, N.A., Shams, S., Ahamad, A., Khan, S.A., Anwar, F. (2015). Essential oils used in aromatherapy: A systemic review. Asian Pacific Journal of Tropical Biomedicine, 5(8), 601-611.

31.De Sousa, A.A.S., Soares, P.M.G., De Almeida, A.N.S., Maia, A.R., De Souza, E.P., Assreuy, A.M.S. (2010). Antispasmodic effect of Mentha piperita essential oil on tracheal smooth muscle of rats. Journal of Ethnopharmacology, 130(2), 433-436.

32.Trevisan, S.C.C., Menezes, A.P.P., Barbalho, S.M., Guiguer, E.L. (2017). Properties of Mentha piperita: A brief review. World Journal of Pharmaceutical and Medical Research, 3(1), 309-313.

33.Sharma, V., Agrawal, R.C. (2013). Glycyrrhiza glabra - A plant for the future. Mintage Journal of Pharmaceutical and Medical Sciences, 2(3), 15-20.

34. Shinwari, Z.K., Khan, I., Naz, S., Hussain, A. (2009). Assessment of antibacterial activity of three plants used in Pakistan to cure respiratory diseases. African Journal of Biotechnology, 8(24), 7082-7086.

35.Kültür, Ş. (2007). Medicinal plants used in Kırklareli Province (Turkey). Journal of Ethnopharmacology, 111(2), 341-364.

36. Yayalacı, Y., Çelik, I., Bat1, B. (2013). Hepatoprotective and antioxidant activity of linden (Tilia platyphyllos L.) infusion against ethanol-induced oxidative stress in rats. The Journal of Membrane Biology, 247(2), 181-188.

37.Chrubasik, C., Roufogalis, B.D., Müller-Ladner, U., Chrubasik, S. (2008). A systematic review on the Rosa canina effect and efficacy profiles. Phytotherapy Research, 22(6), 725-733.

38. Hamidi, S., Vaez, H., Asgharian, P. (2014). Rosa canina as an adjunctive treatment of asthma: A hypothesis. Advances in Bioscience and Clinical Medicine, 3(1), 48-52. 
39.Wenzig, E.M., Widowitz, U., Kunert, O., Chrubasik, S., Bucar, F., Knauder, E., Bauer, R. (2008). Phytochemical composition and in vitro pharmacological activity of two rose hip (Rosa canina L.) preparations. Phytomedicine, 15(10), 826-835.

40.Kılınç, F., Demircan, F., Yıldırım, Y., Yılmaz, Z., Pekkolay, Z., Tuzcu, A.K. (2014). Licorice root (licorice) induced evaluation of the 5 patients presenting with hypertension and hypokalemia. Sakarya Medical Journal, 4(4), 186-190.

41.Moghaddasi, M.S., Kashani, H.H. (2012). Ginger (Zingiber officinale): A review. Journal of Medicinal Plants Research, 6(26), 4255-4258.

42.Uzun, M.B., Aykaç, G., Özçelikay, G. (2014). Bitkisel ürünlerin yanlış kullanımı ve zararları. Lokman Hekim Dergisi, 4(3), 1-5.

43.Biçen, C., Elver, Ö., Erdem, E., Kaya, C., Karataş, A., Dilek, M., Akpolat, T. (2012). Hipertansiyon hastalarında bitkisel ürün kullanımı. Journal of Experimental and Clinical Medicine, 29(2), 109-112.

44.Sim, T.F., Sherriff, J., Hattingh, H.L., Parsons, R., Tee, L.B. (2013). The use of herbal medicines during breastfeeding: a population-based survey in Western Australia. BMC Complementary Medicine and Therapies, 13, 1-10. 